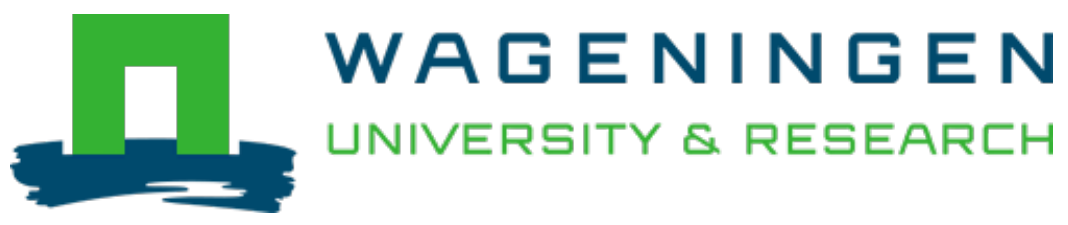

\title{
Impact of the algal-bacterial community structure, physio-types and biological and environmental interactions on the performance of a high rate algal pond treating biogas and wastewater
}

Fuel

Cantera, Sara; Fischer, Peter Q.; Sánchez-Andrea, Irene; Marín, David; Sousa, Diana Z. et al https://doi.org/10.1016/i.fuel.2021.121148

This article is made publicly available in the institutional repository of Wageningen University and Research, under the terms of article $25 \mathrm{fa}$ of the Dutch Copyright Act, also known as the Amendment Taverne. This has been done with explicit consent by the author.

Article $25 \mathrm{fa}$ states that the author of a short scientific work funded either wholly or partially by Dutch public funds is entitled to make that work publicly available for no consideration following a reasonable period of time after the work was first published, provided that clear reference is made to the source of the first publication of the work.

This publication is distributed under The Association of Universities in the Netherlands (VSNU) 'Article $25 \mathrm{fa}$ implementation' project. In this project research outputs of researchers employed by Dutch Universities that comply with the legal requirements of Article 25fa of the Dutch Copyright Act are distributed online and free of cost or other barriers in institutional repositories. Research outputs are distributed six months after their first online publication in the original published version and with proper attribution to the source of the original publication.

You are permitted to download and use the publication for personal purposes. All rights remain with the author(s) and / or copyright owner(s) of this work. Any use of the publication or parts of it other than authorised under article $25 \mathrm{fa}$ of the Dutch Copyright act is prohibited. Wageningen University \& Research and the author(s) of this publication shall not be held responsible or liable for any damages resulting from your (re)use of this publication.

For questions regarding the public availability of this article please contact openscience.library@wur.nl 


\title{
Impact of the algal-bacterial community structure, physio-types and biological and environmental interactions on the performance of a high rate algal pond treating biogas and wastewater
}

\author{
Sara Cantera $^{\mathrm{a}}$, Peter Q. Fischer ${ }^{\mathrm{a}, \mathrm{b}}$, Irene Sánchez-Andrea ${ }^{\mathrm{a}}$, David Marín ${ }^{\mathrm{c}, \mathrm{d}}$, Diana Z. Sousa ${ }^{\mathrm{a}}$, \\ Raúl Muñoz ${ }^{\text {, d, * }}$ \\ ${ }^{a}$ Laboratory of Microbiology, Wageningen University and Research, Stippeneng 4, 6708 WE Wageningen, the Netherlands \\ ${ }^{\mathrm{b}}$ Netherlands Institute for Marine Research. Department of Marine Microbiology and Biogeochemistry, Landsdiep 4, 1797 SZ ' $t$ Horntje, the Netherlands \\ ${ }^{\mathrm{c}}$ Department of Chemical Engineering and Environmental Technology, Universidad de Valladolid, Dr. Mergelina, s/n, Valladolid, Spain \\ ${ }^{\mathrm{d}}$ Institute of Sustainable Processes, Universidad de Valladolid, Spain
}

\section{A R T I C L E I N F O}

\section{Keywords:}

Algal-bacterial photobioreactor

HRAP

Biogas upgrading

Algal-bacterial interaction

Environmental conditions

\begin{abstract}
A B S T R A C T
This study investigated the algal and prokaryotic community structure in an outdoors pilot High Rate Algal Pond (HRAP) that was simultaneously used for the treatment of high-strength wastewater and biogas upgrading. The algal and prokaryotic diversity was analyzed and correlated with biological and environmental parameters, and process quality indicators. The results obtained showed that the dominance of a versatile and resistant algae, such as Chlorella vulgaris, which is tolerant to high $\mathrm{NH}_{4}^{+}$and $\mathrm{CO}_{2}$ concentrations, concomitant to a specific prokaryotic population allowed for the obtention of biomethane with $95.2 \pm 0.7 \% \mathrm{CH}_{4}, 1.4 \pm 0.1 \% \mathrm{CO}_{2}$ and no $\mathrm{H}_{2} \mathrm{~S}$. The bacterial community, fostered by the algal population, the light hours, and photoperiod had an important role on both biogas upgrading, through $\mathrm{O}_{2}$ and $\mathrm{H}_{2} \mathrm{~S}$ elimination, and wastewater treatment. While the algal population was involved in the elimination of the ammonium of the wastewater through assimilation, the bacterial population was the main factor responsible for organic carbon, nitrate and phosphate removal, as well as nitrification. The low oxygen concentrations at night promoted bacterial denitrification, increasing the nitrite concentration in the treated wastewater. Through these findings, this research encourages photosynthetic biogas upgrading combined with wastewater treatment in HRAPs using an inoculum composed of a dominant microalgae, and an enriched prokaryotic population of aerobic chemo-organoheterotrophs, aerobic nitrifiers, and sulfur bacteria. Unlike the bacterial consortium in this study, this designed consortium can avoid the accumulation of nitrite in the cultivation broth and reduce the content of oxygen in the produced biomethane.
\end{abstract}

\section{Introduction}

Photobioreactors have emerged as a promising platform for wastewater treatment based on the symbiosis between microalgae and bacteria [1]. This biotechnology allows the simultaneous removal of organic matter, nutrients and pathogens without the need of mechanical aeration or chemical addition [2]. Moreover, photobioreactors have garnered enormous interest as tools to capture $\mathrm{CO}_{2}$, and bio-transform it into a variety of bio-based products, including biofuels [3].

One of the most promising and cost-effective photobioreactor configurations for the production of biofuels are High Rate Algal Ponds (HRAP). In fact, due to the symbiotic actions of algae and bacteria, recent research positions HRAP as an up-and-coming cost-competitive biotechnology to obtain high quality biomethane coupled with wastewater treatment $[4,5]$. In an HRAP, biomethane is formed in a single stage via removal of $\mathrm{CO}_{2}$ and $\mathrm{H}_{2} \mathrm{~S}$ by the inherent metabolism of bacteria and algae. Moreover, wastewater (typically digestate) acts as the source of nutrients and water to support microbial growth with the simultaneous recovery of nitrogen and phosphorous species from this wastewater. Hence, the treated wastewater can be discharged following the requirements of international legislation (Directive 91/271/EEC). The produced biomethane (which typically complies with the concentrations stablished by most international regulations of $\mathrm{CH}_{4}>90 \%, \mathrm{CO}_{2}<2 \%$, $\mathrm{O}_{2}<0.3 \%$ ) can be used as a substitute of natural gas via its injection into

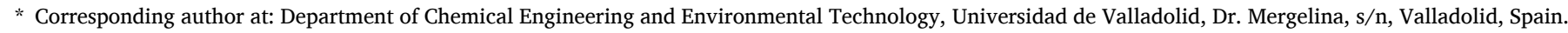

E-mail address: mutora@iq.iuva.es (R. Muñoz).
} 
natural gas grids or use as autogas [6]. However, while there has been extensive research in the past years to enhance the technical performance of HRAPs and to fulfill biomethane standards, the complex microbiology supporting the process is still poorly understood, which is crucial to guarantee the long-term sustainability of this green technology $[1,4,7]$. In HRAPs devoted to biogas upgrading, microalgae and prokaryotes influence each other's physiology and metabolism synergistically [8-10], which represents the basis of this biotechnology. In fact, the prokaryotic and algal communities structure and their interactions have key impacts on algal growth, wastewater treatment and biogas upgrading. Algal growth has impact on $\mathrm{pH}$, temperature and dissolved $\mathrm{O}_{2}$ concentration of the cultivation broth. Wastewater treatment is affected through the removal capacity of $\mathrm{N}$ and $\mathrm{P}$ and ultimately digestate loading rate. Biogas upgrading efficiency is affected through $\mathrm{pH}$ and dissolved oxygen in the cultivation broth [1,11]. Algae are involved in the production of $\mathrm{O}_{2}$, consumption of $\mathrm{CO}_{2}$ and nutrient removal via photosynthesis, while bacteria are in charge of the fixation and regeneration of inorganic nutrients $\left(\mathrm{NH}_{3}, \mathrm{PO}_{4}^{3-}\right.$, and $\mathrm{H}_{2} \mathrm{~S}$ oxidation), consumption of organic matter and production of vitamins and siderophores $[2,8]$. As such, algal and bacterial have important effects on the environmental parameters of an HRAP. Similarly, environmental parameters have effects on gene expression, and can foster some biological pathways over others, thus modifying the microbial structure and the inherent metabolism involved in the biotechnological process in turn $[1,12]$. Thus, fundamental research focused on the study of algalprokaryotes interactions, performance and metabolisms in HRAP, as well as the environmental parameters that affect the growth and cooperation of both communities is necessary to enhance the operation robustness and to guarantee the long-term sustainability of these biotechnologies in real scale applications.

This study investigated the algal-prokaryotic community structure, their biological and environmental interactions, as well as the physiotypes involved in the simultaneous treatment of real digestate coupled with biogas upgrading in an outdoors pilot HRAP operated from December 2016 to October 2017. For this purpose, the dynamics of algal and prokaryotic populations were analyzed and correlated with the environmental conditions affecting the HRAP performance. The optimal algal-prokaryote synergetic composition was evaluated and described on the process quality criteria.

\section{Materials and methods}

\subsection{Experimental set-up}

Process operation was carried out from December 28th 2016 to October 27th of 2017. The pilot experimental plant was composed of an HRAP of 180 L (mmc: Fig. S1) as described by Marín et al. (2018) [7]. Photobioreactor set-up, operation and physicochemical \& instrumental procedures are included in the supplementary material of this article (mmc: sections S1, S2 and S3). Macroscopic performance of the system in terms of biogas upgrading and nutrient removal has been previously published by Marín et al. (2018)[7,13]. Real digestate, used as a nutrient and water source, was obtained from the sludge anaerobic digester of the wastewater treatment plant (WWTP) of Valladolid (mmc: Text S1). A synthetic biogas mixture mimicking biogas from the anaerobic digestion of wastewaters and organic waste, which usually contains $\mathrm{CH}_{4}(70 \%)$, $\mathrm{CO}_{2}(29.5 \%)$ and $\mathrm{H}_{2} \mathrm{~S}(0.5 \%)$ [6]) was fed continuously (mmc: Text $\mathrm{S} 2$ ) to the absorption column interconnected to the HRAP. The environmental parameters monitored in this research were temperature, including ambient and photobioreactor temperatures, maximum monthly insulation, $\mathrm{pH}$ and dissolved oxygen (DO). The assessment of photobioreactor performance was based on the analysis of $\mathrm{CH}_{4}, \mathrm{CO}_{2}$, $\mathrm{H}_{2} \mathrm{~S}, \mathrm{O}_{2}$ and $\mathrm{N}_{2}$ from the synthetic and upgraded biogas (from here on named biomethane). Total inorganic carbon, total nitrogen, $\mathrm{N}-\mathrm{NH}_{4}^{+}, \mathrm{N}$ $\mathrm{NO}_{2}^{-}, \mathrm{N}-\mathrm{NO}_{3}^{-}, \mathrm{P}_{-} \mathrm{PO}_{4}^{3-}, \mathrm{S}-\mathrm{SO}_{4}^{2-}$ and biomass concentrations were measured and considered during the statistical analysis of this study (mmc: Text S3).

For prokaryote and algal community analysis, samples of $100 \mathrm{~mL}$ were drawn at the end of each month. Samples were preserved at $-20 \mathrm{C}$ for later bacterial and archaeal analyses. For the determination of algal community structure, samples were fixed with an acidic lugol's solution, containing neutral lugol's solution (KI (100 g), MilliQ $\mathrm{H}_{2} \mathrm{O}(1000 \mathrm{~mL}), \mathrm{I}_{2}$ (50 g)) mixed with $50 \mathrm{~g}$ of $\mathrm{CH}_{3} \mathrm{COOH}$ and stored at $4{ }^{\circ} \mathrm{C}$. In February, no sample for prokaryotic analysis was taken due to the freezing of the cultivation broth and subsequent technical issues in regard to reactor operation.

\subsection{Inoculum}

The outdoors HRAP was inoculated with an algal culture previously grown in an indoors HRAP [14]. The initial algal biomass concentration was $210 \mathrm{mg}$ total suspended solids $\mathrm{L}^{-1}$. The microalgal inoculum was composed of Leptolyngbya lagerheimii (54\%), Chlorella vulgaris (28\%), Parachlorella kessleri (9\%), Tetradesmus obliquus (5\%) and Mychonastes homosphaera (2\%) (percentage of the number of cells against the total cells). Activated sludge from Valladolid Wastewater treatment plant, with a denitrification-nitrification configuration, was used as the prokaryotic inoculum (mmc: text S2). The identification of microalgae species was conducted by microscopic examination (OLYMPUS IX70, USA) of the cultivation broths according to Marín et al. (2018) [7].

\subsection{Prokaryotic sequencing analysis}

Aliquots of $5 \mathrm{~mL}$ of the cultivation broth of the HRAP from January to October were centrifuged at $9000 \times \mathrm{g}$ for $10 \mathrm{~min}$. The resting pellet was used for DNA extraction and the V4-V5 region of the 16S rRNA gene (universal primers V4: GGACTACHVGGGTWTCTAAT, V5: CCCGTCAATTCMTTTRAGT) was amplified with PCR following the instructions by Kozich et al. (2013)[15]. PCR was performed and normalized according to Phandanouvong-Lozano et al. (2018)[16]. The library was spiked with $10 \%$ PhiX (Illumina) and sequenced using the Illumina MiSeq platform. The 16S rRNA gene sequences were processed using Mothur v1.44.0 following the MiSeq-SOP (https://www.mothur. org/wiki/MiSeq_SOP). Quality filtration was performed using Mothur v1.44.0 according to Phandanouvong-Lozano et al. (2018) [16]. Sequences were then classified into Operational Taxonomic Units (OTUs) using the SILVA 16S rRNA gene reference database (Version: 138). Nucleotide sequence dataset obtained in this study was deposited at DDBJ/ENA/GenBank as bioproject: PRJNA698290 (https://www.ncbi. nlm.nih.gov/bioproject/PRJNA698290). Prior to diversity analysis, rarefaction was calculated with all the sequences per sample (4020 reads were chosen for further analysis, mmc: Fig. S2). Alpha diversity was calculated with the Inverse Simpson Index using Mothur v1.44.0, which quantifies the richness in a community with uniform evenness [16]. Beta diversity among samples was compared by using the Jaccard Index, which measures dissimilarity between two communities based on the taxonomic affiliation and abundance of each OTU [17]. The heat-map of the Jaccard index and the Venn diagrams were developed with Mothur v1.44.0. An Analysis of Molecular Variance (AMOVA) was performed to test differences between months in alpha diversity and whether the spatial separation among the groups in the Jaccard analysis was statistically significant (Mothur v1.44.0).

\subsection{Statistical analysis of the effect of environmental parameters on the prokaryotic and algal community}

ANOVA and post-hoc analyses were used to calculate the differences intra-groups for all the environmental parameters (SPSS ${ }^{\circledR}$ software). The prokaryotic and algal community structure was analyzed using $R$ version 3.6.3 [18]. The main genera of the prokaryotic and algal populations are shown in heat-maps plotted using the package pheatmap. Non-metric dimensional scaling (NMDS) was performed to visualize 
influence of season and algal community on microbial abundance data as discrete data. Statistical significance from these results was calculated with analysis of similarity (ANOSIM) using the package vegan [19]. The influence of each individual continuous environmental and biological parameters on bacterial and algal diversity was assessed using redundancy analysis (RDA) using the package vegan [19]. This method extracts and summarizes the variation in a set of response variables that can be explained by a set of explanatory variables. The statistical significance of this ordination was then calculated with canonical correspondence analysis (CCA) $[18,19]$. To determine the collinearity between environmental parameters, $R$ squared values between all individual parameters were calculated and considered collinear at 0.6 [18].

\section{Results and discussion}

\subsection{Environmental parameters}

The majority of environmental parameters fluctuated along the operation of the HRAP as a result of the inherent seasonal variability of the continental climate prevailing in Valladolid, Spain (Table 1, mmc: Fig. S3-S7). In this study, the environmental data obtained during reactor operation (Marin et al. 2018)[13] were statistically compared between seasons and with the microbial diversity. The environmental parameters monitored were temperature of the HRAP cultivation broth, maximum monthly insulation, $\mathrm{pH}$ and dissolved oxygen concentration (Table 1, mmc: Fig. S3-S7).

The temperatures in the cultivation broth reached values as low as $2.3 \pm 3.1{ }^{\circ} \mathrm{C}$ (January) and $4.8 \pm 2.1{ }^{\circ} \mathrm{C}$ (February), which negatively affected the algal-bacterial activity according to Marin et al. (2018)[7]. The increase in the temperature of the cultivation broth supported higher biomass productivities and biomass concentrations during spring, summer, and autumn [7]. The HRAP average temperatures recorded were $9.2 \pm 3.5^{\circ} \mathrm{C}$ in spring, $17.3 \pm 3.2{ }^{\circ} \mathrm{C}$ in summer and 12.3 $\pm 2.8^{\circ} \mathrm{C}$ in autumn (mmc: Fig. S3). It has been previously reported that algal biomass activity is proportional to the pond temperature up to an optimum, above which, increasing algal respiration and photorespiration reduces the overall biomass productivity $[11,20]$. However, no significant difference at $\mathrm{p}<0.05$ between the average temperatures recorded from April to October was observed in this study (Table 1, mmc: Fig. S5).

Maximum monthly insulation and photoperiod are important parameters to increase algal activity [21]. The maximum monthly insulation recorded during the yearly operation of the HRAP (Table 1, mmc: Fig. S4) corresponded to the spring and summer months, while the minimum insulation was measured in January. Biomass concentration significantly increased during the spring and summer months, and decreased coterminous with the lower maximum monthly insulation of the autumn months (Table 1, mmc: Fig. S5).

Process operation at $\mathrm{pH}$ above 9 can cause nutrient deficiency due to the precipitation of phosphate and stripping of ammonia, although $\mathrm{pH}$ higher than 9 increases $\mathrm{CO}_{2}$ and $\mathrm{H}_{2} \mathrm{~S}$ gas-liquid mass transfer and therefore, improves the biogas upgrading process [4]. Moreover, the use of high $\mathrm{pH}$ prevents biological contamination by undesired microorganisms and favors the dominance of specialized microalgae [1]. In this research, the $\mathrm{pH}$ remained constant at $9.5 \pm 0.4$ throughout the whole operation as a result of the high alkalinity of the cultivation broth (Table 1, mmc: Fig. S6). Additionally, the continuous supply of digestate, a carbon and nutrient rich source, prevented the negative effects of nutrient deficiency characteristic of alkaline media. Finally, the concentrations of dissolved oxygen in the cultivation broth of the HRAP did not show significant differences between months $(\mathrm{p}<0.05)$ (Table 1 , mmc: Fig. S7). Despite an increase in biomass concentration and productivity from April onwards, the dissolved oxygen produced by microalgae seemed to be concomitantly used by the bacterial population [7].

\subsection{Biogas upgrading and digestate treatment performance}

The reactor was fed in continuous mode with biogas containing $70 \%$ $\mathrm{CH}_{4}, 29.5 \% \mathrm{CO}_{2}$ and $0.5 \% \mathrm{H}_{2} \mathrm{~S}$. The best performance of the photobioreactor in terms of biogas upgrading was observed from April until the end of operation (Table 2, mmc: Fig. S8) according to Marin et al. (2018) [7]. In these months, $\mathrm{CH}_{4}$ and $\mathrm{CO}_{2}$ concentrations complied with international regulations for its use as a substitute of natural gas $\left(\mathrm{CH}_{4}=\right.$ $\left.95 \%, \mathrm{CO}_{2}=2 \%\right)$. However, $\mathrm{O}_{2}$ concentrations $(1.3 \pm 0.4 \%)$ exceeded most international biomethane standards of maximum $0.3 \%$ [6]. The highest percentage of $\mathrm{CH}_{4}$ in the upgraded biogas was obtained in August at $96.4 \%$, while the minimum content of methane was recorded in January and February at 90.6 and $91.2 \%$, respectively (Table 2). Concurrently, the $\mathrm{CO}_{2}$ concentration was highest in January, February and March (Table 2). From April onwards, algal activity, enhanced by the favorable environmental conditions, helped to decrease the $\mathrm{CO}_{2}$ concentration down to average values of $1.2 \pm 0.3 \%$ in the upgraded

Table 1

Environmental parameters and process data throughout the one year pilot trial of the HRAP.

\begin{tabular}{|c|c|c|c|c|c|c|}
\hline Months & $\begin{array}{l}\text { Ambient Temperature } \\
\text { ( C) }\end{array}$ & $\begin{array}{l}\text { HRAP Temperature } \\
\left({ }^{\circ} \mathrm{C}\right)\end{array}$ & $\begin{array}{l}\text { Maximum monthly insulation ( } \mu \mathrm{mol} \\
\mathrm{m}^{-2} \mathrm{~s}^{-1} \text { ) }\end{array}$ & pH & $\begin{array}{l}\text { Dissolved Oxygen (mg } \\
\mathrm{L}^{-1} \text { ) }\end{array}$ & $\begin{array}{l}\text { Biomass }(\mathrm{mg} \\
\left.\mathrm{L}^{-1}\right)\end{array}$ \\
\hline January & $1.0 \pm 4.1^{\mathrm{a}}$ & $2.3 \pm 3.1^{\mathrm{a}}$ & 733.4 & $\begin{array}{l}9.4 \pm \\
0.4^{\mathrm{a}}\end{array}$ & $10.9 \pm 1.8^{\mathrm{a}}$ & $105.6 \pm 40^{\mathrm{a}}$ \\
\hline February & $4.8 \pm 2.5^{\mathrm{a}}$ & $4.8 \pm 2.1^{\mathrm{a}}$ & 482.2 & $\begin{array}{l}9.0 \pm \\
0.5^{\mathrm{a}}\end{array}$ & $9.9 \pm 0.6^{\mathrm{a}}$ & $55.0 \pm 30^{\mathrm{b}}$ \\
\hline March & $6.6 \pm 3.6^{\mathrm{a}, \mathrm{b}}$ & $6.0 \pm 2.6^{\mathrm{a}, \mathrm{b}}$ & 1339.7 & $\begin{array}{l}9.4 \pm \\
0.4^{\mathrm{b}}\end{array}$ & $10.6 \pm 2.9^{\mathrm{a}}$ & $167.5 \pm 35^{\mathrm{a}}$ \\
\hline April & $8.7 \pm 3.6^{\mathrm{a}, \mathrm{b}, \mathrm{c}}$ & $8.8 \pm 3.3^{\mathrm{a}, \mathrm{b}, \mathrm{c}}$ & 1154.8 & $\begin{array}{l}9.6 \pm \\
0.3^{\mathrm{b}}\end{array}$ & $7.7 \pm 1.4^{\mathrm{a}}$ & $244.3 \pm 36^{a}$ \\
\hline May & $13.3 \pm 3.8^{\mathrm{b}, \mathrm{c}}$ & $12.9 \pm 3.4^{\mathrm{b}, \mathrm{c}}$ & 1707.0 & $\begin{array}{l}9.3 \pm \\
0.2^{\mathrm{a}}\end{array}$ & $7.5 \pm 2.1^{\mathrm{a}}$ & $581.1 \pm 32^{c}$ \\
\hline June & $19.5 \pm 4.5^{c}$ & $17.8 \pm 4.0^{c}$ & 717.8 & $\begin{array}{l}9.5 \pm \\
0.2^{\mathrm{b}}\end{array}$ & $6.8 \pm 1.4^{\mathrm{a}}$ & $518.8 \pm 52^{c}$ \\
\hline July & $20.3 \pm 4.0^{c}$ & $17.9 \pm 3.1^{\mathrm{c}}$ & 1556.5 & $\begin{array}{l}9.4 \pm \\
0.3^{\mathrm{b}}\end{array}$ & $7.9 \pm 3.3^{\mathrm{a}}$ & $571.3 \pm 62^{c}$ \\
\hline August & $18.2 \pm 3.1^{\mathrm{c}}$ & $16.2 \pm 2.4^{\mathrm{c}}$ & 1209.8 & $\begin{array}{l}9.6 \pm \\
0.2^{\mathrm{b}}\end{array}$ & $5.3 \pm 2.0^{\mathrm{a}}$ & $625.0 \pm 80^{c}$ \\
\hline September & $13.6 \pm 4.0^{\mathrm{b}, \mathrm{c}}$ & $13.7 \pm 2.8^{\mathrm{b}, \mathrm{c}}$ & 1305.6 & $\begin{array}{l}9.8 \pm \\
0.1^{\mathrm{c}}\end{array}$ & $6.4 \pm 1.5^{\mathrm{a}}$ & $514.0 \pm 71^{c}$ \\
\hline October & $10.2 \pm 3.7^{\mathrm{b}, \mathrm{c}}$ & $11.0 \pm 2.8^{\mathrm{b}, \mathrm{c}}$ & 864.7 & $\begin{array}{l}9.6 \pm \\
0.1^{\mathrm{c}}\end{array}$ & $6.0 \pm 1.6^{a}$ & $423.5 \pm 40^{c}$ \\
\hline
\end{tabular}

Mean values within a column and component followed by different superscript letters were significantly different at $\mathrm{p}$ value $<0.05$. Means \pm SD. 
Table 2

Upgraded biogas composition and cultivation broth $\mathrm{N}, \mathrm{S}$, and P concentrations after treatment during the operation of the HRAP.

\begin{tabular}{|c|c|c|c|c|c|c|c|c|c|}
\hline \multirow[b]{2}{*}{ Months } & \multicolumn{4}{|c|}{ Upgraded biogas (biomethane) } & \multicolumn{5}{|c|}{$\mathrm{N}, \mathrm{S}$, and $\mathrm{P}$ concentrations in the liquid broth } \\
\hline & $\mathrm{CO}_{2}(\%)$ & $\mathrm{CH}_{4}(\%)$ & $\mathrm{O}_{2}(\%)$ & $\mathrm{N}_{2}(\%)$ & $\mathrm{SO}_{4}^{2-}\left(\mathrm{mg} \mathrm{L}^{-1}\right)$ & $\mathrm{N}-\mathrm{NH}_{4}^{+}\left(\mathrm{mg} \mathrm{L}^{-1}\right)$ & $\mathrm{N}-\mathrm{NO}_{2}^{-}\left(\mathrm{mg} \mathrm{L}^{-1}\right)$ & $\mathrm{N}-\mathrm{NO}_{3}^{-}\left(\mathrm{mg} \mathrm{L}^{-1}\right)$ & $\mathrm{P}^{-\mathrm{PO}_{4}^{3-}}\left(\mathrm{mg} \mathrm{L}^{-1}\right)$ \\
\hline January & $5.0 \pm 1.2^{\mathrm{a}}$ & $90.6 \pm 2.2^{\mathrm{a}, \mathrm{b}}$ & $1.3 \pm 0.5^{\mathrm{a}}$ & $3.6 \pm 1.4^{\mathrm{a}}$ & $611.3 \pm 86 .^{\mathrm{a}}$ & $81.6 \pm 18.4^{\mathrm{a}}$ & $54.3 \pm 3.9^{\mathrm{a}}$ & $121.6 \pm 8.6^{\mathrm{a}}$ & $5.3 \pm 0.7^{\mathrm{a}}$ \\
\hline February & $4.1 \pm 0.6^{\mathrm{a}}$ & $91.2 \pm 0.8^{\mathrm{a}, \mathrm{b}}$ & $1.2 \pm 0.2^{\mathrm{a}}$ & $3.5 \pm 0.5^{\mathrm{a}}$ & $506.2 \pm 35.2^{\mathrm{a}}$ & $62.8 \pm 12.5^{\mathrm{a}}$ & $47.7 \pm 2.8^{\mathrm{a}}$ & $82.0 \pm 10.5^{\mathrm{b}}$ & $6.9 \pm 0.4^{\mathrm{a}}$ \\
\hline March & $4.2 \pm 0.8^{\mathrm{a}}$ & $93.0 \pm 1.0^{\mathrm{b}, \mathrm{c}}$ & $0.9 \pm 0.8^{\mathrm{a}}$ & $1.9 \pm 0.5^{\mathrm{a}}$ & $643.4 \pm 60.6^{\mathrm{a}}$ & $16.2 \pm 20.1^{\mathrm{b}}$ & $69.0 \pm 12.2^{\mathrm{a}}$ & $72.6 \pm 6.5^{c}$ & $13.0 \pm 1.6^{\mathrm{b}}$ \\
\hline April & $2.5 \pm 0.7^{\mathrm{b}}$ & $94.9 \pm 1.4^{\mathrm{c}}$ & $0.8 \pm 0.3^{\mathrm{a}}$ & $1.9 \pm 0.4^{\mathrm{a}}$ & $713.7 \pm 111.3^{\mathrm{a}}$ & $0.9 \pm 2.3^{\mathrm{b}}$ & $99.4 \pm 6.3^{\mathrm{b}}$ & $33.0 \pm 20.8^{\mathrm{d}}$ & $11.3 \pm 1.8^{\mathrm{b}}$ \\
\hline May & $1.4 \pm 0.4^{\mathrm{b}}$ & $94.7 \pm 1.6^{c}$ & $1.7 \pm 1.0^{\mathrm{a}}$ & $2.2 \pm 0.7^{\mathrm{a}}$ & $848.7 \pm 109.0^{b}$ & $2.4 \pm 3.6^{\mathrm{b}}$ & $113.3 \pm 7.4^{b}$ & $10.9 \pm 7.9^{d}$ & $14.4 \pm 2.6^{\mathrm{b}, \mathrm{c}}$ \\
\hline June & $1.2 \pm 0.3^{\mathrm{b}}$ & $95.4 \pm 1.5^{c}$ & $1.4 \pm 0.7^{\mathrm{a}}$ & $2.0 \pm 0.8^{\mathrm{a}}$ & $992.5 \pm 100.7^{\mathrm{b}}$ & $3.5 \pm 5.4^{\mathrm{b}}$ & $132.1 \pm 6.5^{b, c}$ & $13.4 \pm 7.4^{\mathrm{d}}$ & $16.3 \pm 1.9^{\mathrm{v}}$ \\
\hline July & $1.2 \pm 0.3^{\mathrm{b}}$ & $95.0 \pm 1.8^{c}$ & $1.7 \pm 0.9^{\mathrm{a}}$ & $2.0 \pm 0.9^{\mathrm{a}}$ & $1139.9 \pm 75.0^{c}$ & $7.7 \pm 4.6^{\mathrm{b}}$ & $125.0 \pm 8.1^{\mathrm{b}, \mathrm{c}}$ & $31.2 \pm 7.0^{\mathrm{d}}$ & $18.1 \pm 2.0^{\mathrm{v}}$ \\
\hline August & $1.2 \pm 0.3^{\mathrm{b}}$ & $96.4 \pm 1.3^{c}$ & $1.0 \pm 0.4^{\mathrm{a}}$ & $1.4 \pm 0.9^{\mathrm{a}}$ & $1225.8 \pm 56.6^{c}$ & $2.8 \pm 0.9^{\mathrm{b}}$ & $146.8 \pm 10.7^{c}$ & $38.1 \pm 15.8^{d}$ & $17.3 \pm 2.5^{\mathrm{v}}$ \\
\hline September & $1.4 \pm 0.3^{\mathrm{b}}$ & $94.3 \pm 1.6^{\mathrm{c}}$ & $1.9 \pm 0.9^{\mathrm{a}}$ & $2.4 \pm 0.7^{\mathrm{a}}$ & $1298.7 \pm 93.0^{c}$ & $7.8 \pm 5.2^{\mathrm{b}}$ & $187.7 \pm 18.7^{\mathrm{d}}$ & $35.5 \pm 7.1^{\mathrm{d}}$ & $18.2 \pm 2.3^{\mathrm{v}}$ \\
\hline October & $1.3 \pm 0.3^{\mathrm{b}}$ & $95.4 \pm 0.6^{c}$ & $0.8 \pm 0.2^{\mathrm{a}}$ & $2.5 \pm 0.6^{\mathrm{a}}$ & $1347.8 \pm 82.8^{c}$ & $9.7 \pm 3.5^{\mathrm{b}}$ & $216.1 \pm 9.4^{\mathrm{e}}$ & $27.8 \pm 12.5^{\mathrm{d}}$ & $19.6 \pm 4.1^{\mathrm{v}}$ \\
\hline
\end{tabular}

Mean values within a column and component followed by different superscript letters were significantly different at $\mathrm{p}$ value $<0.05$. Means \pm SD.

biogas. These values were similar to those obtained in an outdoors HRAP for biogas upgrading operated during summer with Chlorella species as the main algal species [4]. However, the $\mathrm{CO}_{2}$ removal and final $\mathrm{CH}_{4}$ content obtained in an indoors HRAP devoted to biogas upgrading with an algal population dominated by the genera Chlorella and Mychonastes, was overall higher $\left(0.4 \pm 0.3 \% \mathrm{CO}_{2}\right.$ and $\left.96.2 \pm 0.7 \% \mathrm{CH}_{4}\right)[5]$.

According to the collinearity analysis, $\mathrm{CH}_{4}$ and $\mathrm{CO}_{2}$ concentrations in biomethane were statistically influenced by the temperature of the HRAP and the maximum monthly insulation (Table 3), both parameters being crucial for bacterial and algal growth [20]. Lower temperatures increase $\mathrm{CH}_{4}$ and $\mathrm{CO}_{2}$ aqueous solubility [22]. Nevertheless, $\mathrm{CO}_{2}$ concentration in the upgraded biogas was higher during winter likely due to a lower $\mathrm{CO}_{2}$ biological fixation.

Another factor that affected $\mathrm{CH}_{4}$ and $\mathrm{CO}_{2}$ concentration was the maximum monthly insulation. The lower number of sun hours and monthly insulation negatively affected the fixation of $\mathrm{CO}_{2}$, which resulted in higher concentrations of this gas in the biomethane and negatively affected biomethane quality.

The slight fluctuations of $\mathrm{pH}$ observed during operation did not correlate with the $\mathrm{CH}_{4}$ and $\mathrm{CO}_{2}$ percentage detected in the upgraded biogas (Table 3). During operation, part of the inorganic carbon was present in the cultivation broth as carbonate and bicarbonate due to the high pH of the culture broth (mmc: Fig. S9). IC concentrations in the HRAP increased from 1821 to $4138 \mathrm{mg} \mathrm{L}^{-1}$, this increase was correlated with the HRAP temperature (which induced high evaporation rates) and with the $\mathrm{pH}$ and to a lesser degree with the sulphate, $\mathrm{CO}_{2}$ and dissolved oxygen (Table 3 ).

Another important contaminant in biogas, sulfide $\left(\mathrm{H}_{2} \mathrm{~S}\right)$, was completely removed during operation in the HRAP. This finding was in accordance to other studies of photosynthetic biogas upgrading in indoors and outdoors HRAPs $[4,5]$. As a result of the elimination of $\mathrm{H}_{2} \mathrm{~S}$, an increase in $\mathrm{SO}_{4}^{2-}$ concentrations in the cultivation broth from $611.3 \pm$ $86.1 \mathrm{mg} \mathrm{L}^{-1}$ (January) to $1347.8 \pm 82.8 \mathrm{mg} \mathrm{L}^{-1}$ (October) was recorded (Table 2). This $\mathrm{SO}_{4}^{2-}$ increase was not statistically correlated with the maximum monthly insulation, but was impacted by temperature and the dissolved oxygen of the culture broth (Table 3, mmc: Fig. S10). Hence, the increasing concentration of sulfate was probably caused by the aerobic bacterial oxidation of $\mathrm{H}_{2} \mathrm{~S}$ and its accumulation a result of the high evaporation rates and negligible effluent.

The concentration of $\mathrm{N}_{2}$ in biomethane ranged from $3.6 \pm 1.4 \%$ (January) to $1.4 \pm 0.9 \%$ (August), while $\mathrm{O}_{2}$ concentrations ranged from $1.3 \pm 0.5 \%$ (January) to $0.8 \pm 0.2 \%$ (October). $\mathrm{N}_{2}$ and $\mathrm{O}_{2}$ concentrations in the biomethane did not show significant differences during the tested period according to a multifactor post-hoc statistical analysis $(\mathrm{p}<0.05)$ (Table 2). The values measured were comparable to those found in similar photobioreactors for biogas upgrading $[5,23]$. Both gases have low solubility in water, with Henry constants of oxygen at 33.3 and nitrogen at 63.0 [22]. Despite lower temperatures in the HRAP which could have increased $\mathrm{O}_{2}$ and $\mathrm{N}_{2}$ solubility, the collinearity test showed that they were not correlated with these environmental parameters (Table 3). Thus, the low concentrations of both gases in the biomethane were probably related with the operation of the system. Thus, the low L/ $\mathrm{G}$ ratio in the biogas absorption column [4] likely supported the low values of $\mathrm{N}_{2}$ and $\mathrm{O}_{2}$ observed.

A progressive decrease in $\mathrm{N}-\mathrm{NH}_{4}^{+}$and $\mathrm{N}-\mathrm{NO}_{3}^{-}$concentrations in the cultivation broth was observed during HRAP operation (Table 2; mmc: Fig. S11, S12). $\mathrm{N}-\mathrm{NO}_{3}^{-}$decreased from April onwards from $121.6 \pm 8.6$ $\mathrm{mg} \mathrm{L}^{-1}$ in January to $27.8 \pm 12.5 \mathrm{mg} \mathrm{L}^{-1}$ at the end of operation, and $\mathrm{N}$ $\mathrm{NH}_{4}^{+}$dropped from $81.6 \pm 18.4 \mathrm{mg} \mathrm{L}^{-1}$ in January to average values of $5.0 \pm 3.4 \mathrm{mg} \mathrm{L}^{-1}$ during spring and summer. On the contrary, $\mathrm{N}-\mathrm{NO}_{2}-$ concentration increased progressively from $54.3 \pm 3.9 \mathrm{mg} \mathrm{L}^{-1}$ in January to $216.1 \pm 9.4 \mathrm{mg} \mathrm{L}^{-1}$ by October. Temperature and dissolved

Table 3

Co-linearity matrix of environmental and biological parameters.

\begin{tabular}{|c|c|c|c|c|c|c|c|c|c|c|c|c|c|}
\hline \multirow[t]{14}{*}{ Temp } & $0.70^{*}$ & 0.45 & $0.80 *$ & $0.80^{*}$ & $0.78^{*}$ & $0.81 *$ & 0.56 & 0.37 & $0.77^{*}$ & $0.83^{*}$ & $0.82 *$ & $0.82^{*}$ & $0.86^{*}$ \\
\hline & Light & 0.39 & 0.46 & 0.45 & $0.82^{*}$ & $0.87^{*}$ & 0.45 & 0.27 & $0.86^{*}$ & $0.60^{*}$ & $0.94 *$ & 0.47 & 0.5 \\
\hline & & pH & $0.65^{*}$ & $0.77^{*}$ & 0.50 & 0.53 & 0.26 & 0.17 & 0.52 & $0.8^{*}$ & 0.48 & 0.49 & 0.69 * \\
\hline & & & DO & $0.75^{*}$ & 0.54 & $0.63^{*}$ & 0.27 & 0.51 & $0.72^{*}$ & $0.82^{*}$ & $0.62^{*}$ & $0.76^{*}$ & 0.78 * \\
\hline & & & & IC & $0.71^{*}$ & $0.69 *$ & $0.61^{*}$ & 0.17 & 0.57 & $0.95^{*}$ & $0.63^{*}$ & $0.76^{*}$ & $0.98 *$ \\
\hline & & & & & $\mathrm{CO}_{2}$ & $0.96^{*}$ & $0.7^{*}$ & 0.16 & $0.65^{*}$ & $0.79^{*}$ & $0.94 *$ & 0.41 & 0.78 * \\
\hline & & & & & & $\mathrm{CH}_{4}$ & 0.51 & 0.1 & $0.77^{*}$ & $0.77^{*}$ & $0.95^{*}$ & 0.5 & $0.76^{*}$ \\
\hline & & & & & & & $\mathrm{O}_{2}$ & 0.43 & 0.25 & $0.67^{*}$ & $0.62 *$ & 0.34 & $0.67^{*}$ \\
\hline & & & & & & & & $\mathbf{N}_{2}$ & $0.66^{*}$ & 0.15 & 0.17 & $0.66^{*}$ & 0.15 \\
\hline & & & & & & & & & $\mathrm{NH}_{4}$ & $0.68^{*}$ & $0.82^{*}$ & $0.77^{*}$ & 0.59 \\
\hline & & & & & & & & & & $\mathrm{NO}_{2}^{-}$ & $0.77^{*}$ & $0.73^{*}$ & $0.95^{*}$ \\
\hline & & & & & & & & & & & $\mathrm{NO}_{3}^{-}$ & 0.53 & $0.7^{*}$ \\
\hline & & & & & & & & & & & & $\mathbf{P O}_{4}^{3-}$ & $0.75^{*}$ \\
\hline & & & & & & & & & & & & & $\mathrm{SO}_{4}^{2-}$ \\
\hline
\end{tabular}

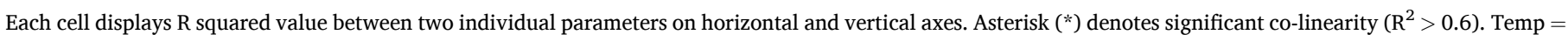

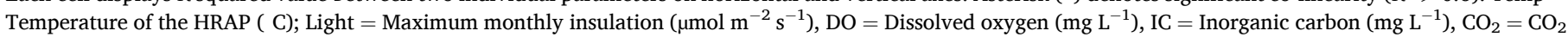

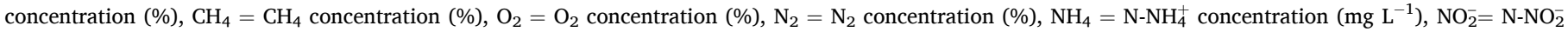
concentration $\left(\mathrm{mg} \mathrm{L}^{-1}\right), \mathrm{NO}_{3}^{-}=\mathrm{N}-\mathrm{NO}_{3}^{-}$concentration $\left(\mathrm{mg} \mathrm{L}^{-1}\right), \mathrm{PO}_{4}^{3}=\mathrm{P}_{-} \mathrm{PO}_{4}^{3-}$ concentration $\left(\mathrm{mg} \mathrm{L}^{-1}\right), \mathrm{SO}_{4}^{2-}=\mathrm{SO}_{4}^{2-}$ concentration $\left(\mathrm{mg} \mathrm{L}^{-1}\right)$. 
oxygen were significantly correlated with the concentrations of the three nitrogen species, while light correlated with ammonia and nitrate, but not with nitrite (Table 3 ). This suggests that photosynthetic activity was decoupled from nitrite synthesis, and probably the algal community assimilated $\mathrm{N}-\mathrm{NH}_{4}^{+}$and $\mathrm{N}-\mathrm{NO}_{3}^{-}$as nitrogen sources [24], while prokaryotes being responsible for the increase in nitrite concentration in the culture broth.

The concentration of $\mathrm{P}_{-} \mathrm{PO}_{4}^{3-}$ slightly increased in the cultivation broth of the HRAP during operation (Table 2). The influent exhibited P$\mathrm{PO}_{4}^{3-}$ concentrations ranging from 100 to $30 \mathrm{mg} \mathrm{L}^{-1}$ (mcc: Fig. S13), while the concentrations found in the culture broth of the HRAP after biological treatment ranged from $5.3 \mathrm{mg} \mathrm{L}^{-1}$ in January to $19.6 \mathrm{mg} \mathrm{L}^{-1}$ in October. $\mathrm{P}_{-} \mathrm{PO}_{4}^{3-}$ recovery in the form of biomass revealed that $<25 \%$ of the $\mathrm{P}_{-} \mathrm{PO}_{4}^{3-}$ was assimilated in the first months of operation. $\mathrm{P}_{-} \mathrm{PO}_{4}^{3-}$ concentrations were correlated with the temperature of the HRAP. Thus, the majority of $\mathrm{P}_{-} \mathrm{PO}_{4}^{3-}$ probably precipitated at the high $\mathrm{pH}$ of the cultivation broth during the winter months (January and February) [4], while from March onwards the majority of $\mathrm{P}_{-} \mathrm{PO}_{4}^{3-}$ was recovered in the harvested biomass (mmc: Table S1).

\subsection{Prokaryotic diversity and community structure}

The 16S rRNA gene sequence analysis for the prokaryotic population of the HRAP revealed the presence of 1718 total OTUs affiliated to 161 bacterial genera and 11 archaeal genera. Prokaryotic richness differed between different samples, sharing $<50 \%$ of the total species within samples from different months (mmc; Fig. S14). The prokaryotic community that showed the highest richness was that one of July, with 760 OTUs, while the lowest richness was observed in the sample from May (280 OTUs), August (347 OTUs) and September (403 OTUs). The alpha diversity analysis showed that the prokaryotic population differed significantly during the yearly operation (AMOVA, $\mathrm{p}<0.05$ ) (Fig. 1A). According to the Jaccard index for Beta Diversity, there was a progressive change in the population. The most dissimilar prokaryotic communities were present in January and October, with $<20 \%$ similarity with the majority of months (Fig. 1B), while the prokaryotic communities most similar to other months were in June and July, likely due to the higher diversity observed during these months.

Fig. 2 displays a heat-map of the 50 overall most abundant bacterial genera in the HRAP (information on the monthly bacterial composition data at phylum taxonomic level, and all bacterial genera detected can be found in supplementary Fig. S15 and Table S2). At the start of the operation (January), sequences belonging to the Pseudomonas genus were the most dominant representing $28 \%$ of the total sequences. Pseudomonas species are versatile heterotrophs often found in wastewater treatment bioreactors [25]. However, sequences belonging to this genus disappeared in the next months (Fig. 2). Other genera also accounted for a significant number of sequences of the microbial community, such as Lentimicrobium (8.1\%), Caldilinea (7.0\%), Acinetobacter (6.6\%) and Comamonas (6.3\%) which were most likely abundant during the winter months due to the continuous supply of digestate to the HRAP. Members of Lentimicrobium are known anaerobic heterotrophs [26] and Caldilinea, Comamonas and Acinetobacter are linked to denitrification and aerobic respiration of complex organic material coupled to organic matter oxidation [27]. In March, the increasing maximum monthly insulation and temperatures favored the growth of (facultative) photosynthetic bacteria such as members of the genus Rhodobacter ( $9.7 \%$ relative abundance), which can perform anoxygenic photosynthesis, but also aerobic and anaerobic respiration and fermentation $[28,29]$.

A significant share of the most representative microorganisms identified in March exhibited nitrate reduction capabilities such as some members of the above mentioned genus Rhodobacter, and several members from the genera Caldilinea (9.5\%), Acinetobacter (5.9\%) and Aquimonas (3.4\%), as well as other members from the family Rhodobacteraceae $(2.9 \%) \quad[27,30,31]$. Some chemo-organoheterotrophic

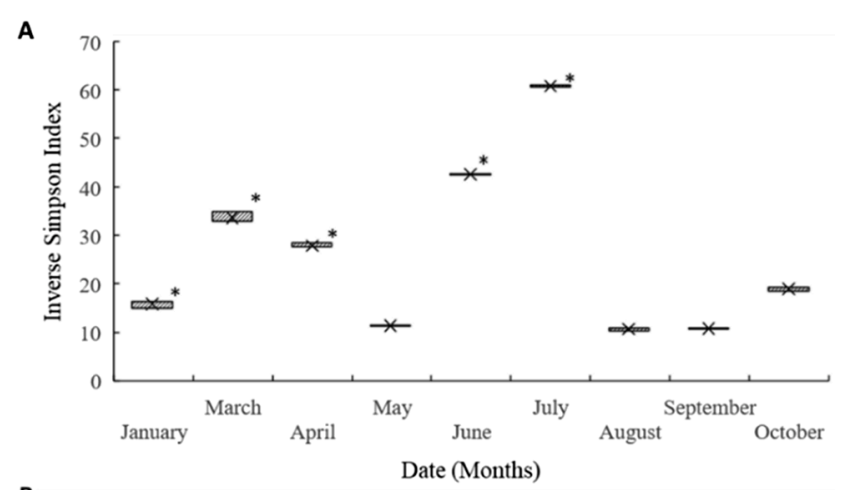

B

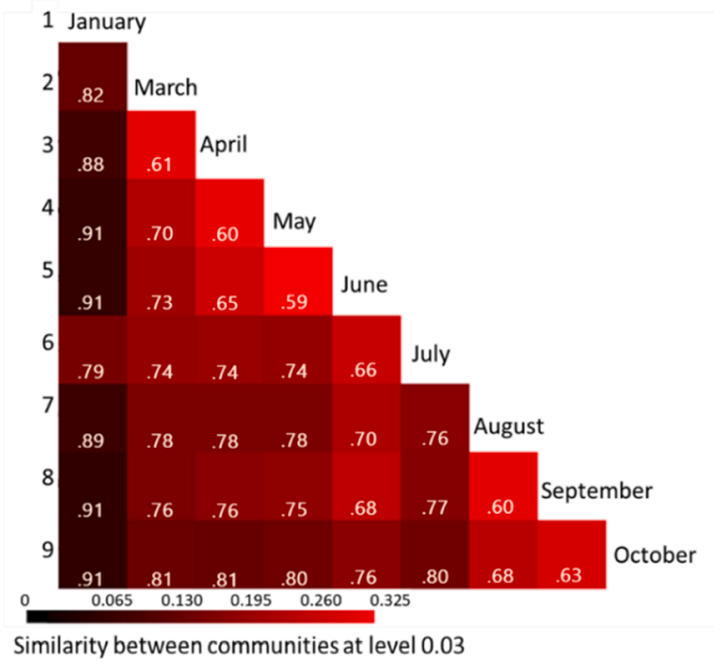

Fig. 1. A. Prokaryotic alpha diversity by season measured using the Inverse Simpson Index. *: AMOVA, $\mathrm{p}<0.05$ from the rest of months. The label for the OTUs was 0.03 . B. Heat-map of prokaryotic beta diversity calculated with the Jaccard index (represented by numbers inside the graph's squares for each month: 0 means minimum dissimilarity and 1 maximum dissimilarity). Red colors in the heatmap indicate communities that are more similar than those with black colors at level 0.03 . (For interpretation of the references to colour in this figure legend, the reader is referred to the web version of this article.)

genera were also detected, with fermenters and respirers members such as Lactococcus (7.8\%), Luteolibacter (6.0\%), Lentimicrobium (4.8\%) and Trichococcus (3.9\%), which were probably feeding on the residual concentrations of organic matter present in the digestate. In the following spring months, April and May, photosynthetic organisms related with sulfur oxidation (Chromatiaceae, Rhodobacter), as well as chemo-organoheterotrophs (Trichococcus, Lactococcus, Luteolibacter), represented the most abundant fraction of the sequences. Photosynthetic population was mainly represented by two taxa, Chromatiaceae family members $(10.3 \%$ and $18.4 \%$ relative abundance of the total sequences in April and May, respectively) and Rhodobacter members (9.0\% and 4.1\% relative abundance of the total sequences in April and May, respectively). Chromatiaceae comprises purple sulfur bacteria. Members of this family perform anoxygenic photosynthesis, oxidizing sulfide to elemental sulfur, which can then be further oxidized to sulfate and therefore were probably involved in oxidizing $\mathrm{H}_{2} \mathrm{~S}$ from biogas [32]. Another abundant genus was Trichococcus (18.4 and 27\% in April and May, respectively), the members of which are related with chemoorganoheterotrophy and were probably feeding on the organic matter of the digestate [33]. Furthermore, bacterial population during these months contained some potential denitrifiers which represented 8 and $17 \%$ relative abundance, such as the genus Caldilinea, Acinetobacter, Chryseobacterium and the genus Novosphingobium [34], as well as fermentative bacteria such as Lactococcus (5.4 and 2.1\% in April and May, respectively) and Flavobacterium (3.5 and 2.0\% in April and May, 

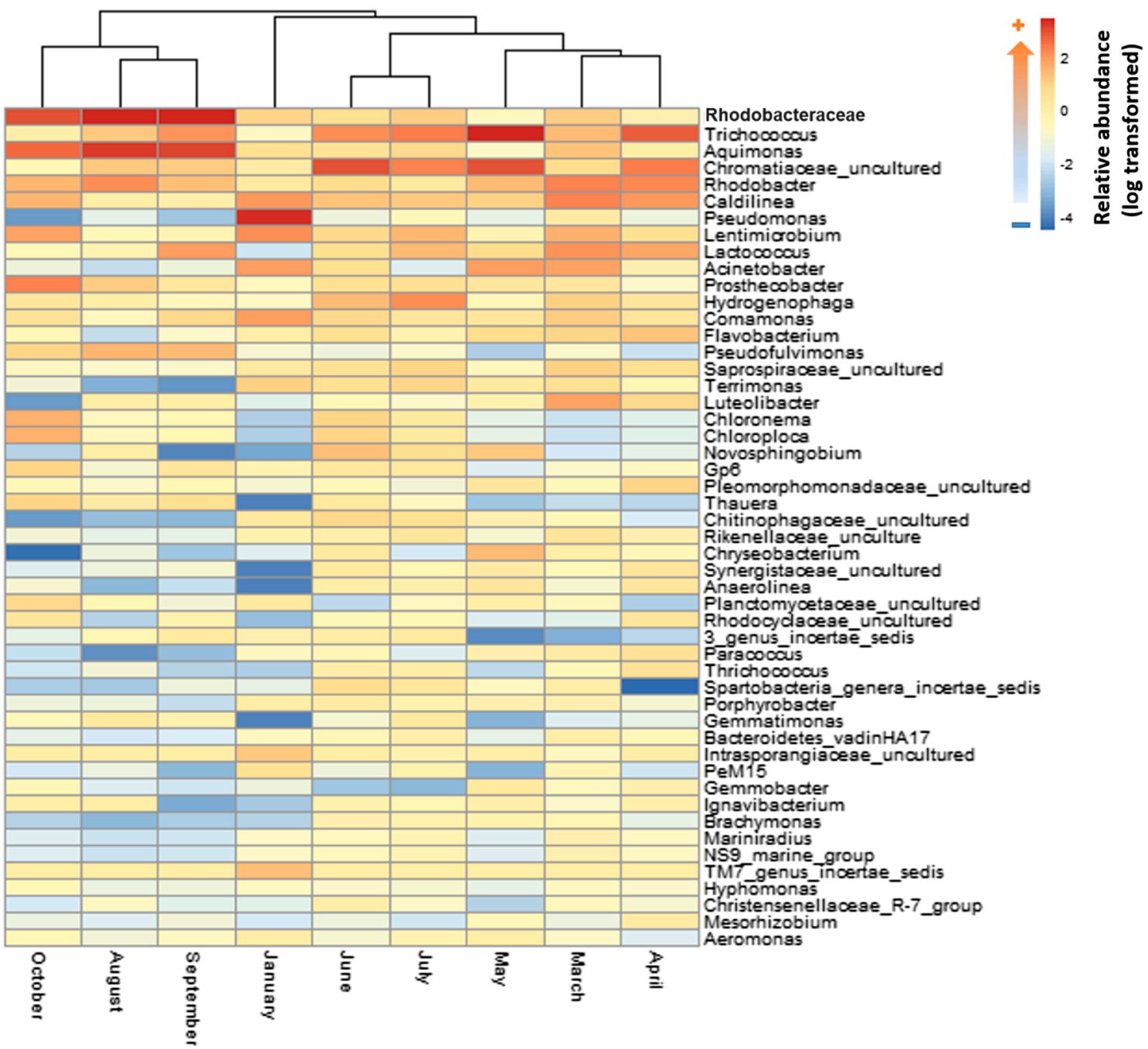

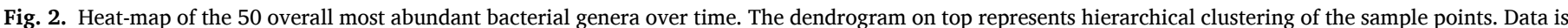

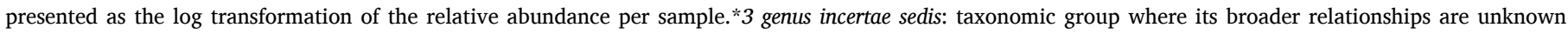
or undefined.

respectively). In June and July, Chromatiaceae members remained the most abundant family (18.0 and $10 \%$ in June and July, respectively). Further microbial diversity was not as functionality driven and was dominated by a mix of chemo-organoheterotrophic, nitrate reducer and hydrogen oxidizer members, with no clearly abundant genera This was reflected in the high alpha diversity index of these months (Fig. 1A).

However, a shift in the bacterial community towards a more specialized population dominated by nitrate utilizing microorganisms was observed in August and September. In these two months, the bacterial community was dominated by members of the family Rhodobacteraceae (30.0 and $28.5 \%$ in August and September, respectively), whose members are commonly involved in denitrification [35]. In addition, Aquimonas represented 22.0 and $21.7 \%$ of the bacterial population in August and September, respectively. Further dominant genera in these months were the photosynthetic genus Rhodobacter $(8.0 \%$ in August and 3.7\% in September) and the family Chromatiaceae (3.1 and $2.8 \%$, respectively), however their abundance was lower in comparison with the previous months. This could have occurred due to the reduction in maximum monthly insulation from August onwards. Chemoorganoheterotrophs were the third most abundant group represented by genera such as Pseudofulvimonas, Trichococcus, Prosthecobacter and Lactococcus. October exhibited a similar bacterial population structure, with Rhodonobacteraceae and Aquimonas dominating the bacterial population, but with lower relative abundances (18.0 and 14.0\%, respectively). Rhodobacter (4.3\%) and other anoxygenic photosynthetic bacteria associated to lower maximum monthly insulation requirements, such as Chloronema (4.8\%) and Chloroploca (4.7\%), increased their abundance during October. Prosthecobacter $(9.4 \%)$, Lentimicrobium (6.0\%) and Caldilinea (4.5\%) were also dominant in October.

Overall, the bacterial community was dominated by members capable of performing anoxygenic photosynthesis, sulfur oxidation, aerobic respiration, denitrification and fermentation. Although the presence of oxygen should have inhibited denitrification, the lower values of oxygen during the night, or in the settler, and the high concentration of denitrifiers fed from the digestate could have prompted the transformation of nitrate into nitrite. This fact could have been related with the increased nitrite accumulation and nitrate depletion in the cultivation broth during the last months of operation. These findings suggest that the bacterial population identified in this research was responsible for the majority of organic carbon consumption, $\mathrm{H}_{2} \mathrm{~S}$ elimination and nitrate reduction in the HRAP system. Some interesting genera for process performance appeared in the bioreactor in very small amounts. For example, methanotrophic and methylotrophic genera such as Methylobacillus, Methylomonas, Methylobacterium and Methylophilus were detected at very low percentages with similar values during operation ( $\sim 0.6 \%$ of relative abundance) and therefore did not significantly affect the concentrations of methane during operation. These 
neutrophilic methanotrophs likely had difficulties to grow at the high $\mathrm{pH}$ of the HRAP and at the low $\mathrm{O}_{2}$ and $\mathrm{CH}_{4}$ concentrations of the culture broth. This is not surprising, as low mass transference of both gasses to the microbial community of the HRAP was expected due to the high Henry constants of $\mathrm{O}_{2}$ and $\mathrm{CH}_{4}[22,36]$. Nitrifiers were also detected. In the case of ammonia aerobic oxidizers, sequences from the family Nitrosomonadaceae were found at a very low relative abundance $(0.2 \%)$, while nitrite aerobic oxidizers were mainly represented by the genus Nitrospira (0.2\%)[27]. Even if the relative abundance of nitrifiers was low, they played an important role on the oxidation of ammonium and the formation of nitrite and nitrate along operation. This bacterial community was similar to that found in other photobioreactors devoted to wastewater treatment combined with biomethane production $[14,37,38]$.

The archaeal analysis showed that all sequences detected belonged to methanogens, the most predominant genus being Methanomethylovorans (Fig. S16). However, methanogens were probably detected in the HRAP due to digestate feed and they were likely not active during operation at the oxygen concentrations found in the HRAP. More studies about the archaeal population should be developed in photobioreactors to determine the possible contribution of methanogens to methane production at low oxygen concentrations during biogas upgrading.

\subsection{Algal community structure}

Even though the HRAP was inoculated with a mixed inoculum of green algae and cyanobacteria, Chlorella vulgaris efficiently outcompeted the rest of microalgae. Indeed, this chlorophytum was the main microalga during reactor operation (Table 4). This green alga is very versatile and resists a wide range of pollutants and environmental conditions [21]. Moreover, the genus Chlorella typically exhibits a dual phototrophic and heterotrophic metabolism, which might also explain its abundance in wastewater treatment systems [1]. In January, there was a relatively mixed population of green algae and cyanobacteria. Cyanobacteria dominated with a relative abundance of $66.1 \%$, represented by Leptolyngbya lagerheimii (62.6\%) and Pseudanabaena sp. The rest of the species belonged to the phylum Chlorophyta, with Tetradesmus obliquus (15.3\%), C. vulgaris (12.0\%), C. minutissima (2.1\%) and Parachlorella kessleri (4.4\%) as the dominant species. In February, cyanobacteria were not observed. Westella (76.2\%) became the dominant green algae along with C. vulgaris (14.3\%) and Desmodesmus opoliensis (9.5\%). However, during spring and summer, $C$. vulgaris became the dominant species coexisting with a small population of Scenedesmus pecsensis $(4.8 \%)$ in March, while from April to August, C. vulgaris was the only microalga observed in the cultivation broth of the HRAP.

Other microalgae started to grow in the HRAP in autumn and the population became more diverse. Although, $C$. vulgaris still represented an important part of the microalgae community (36.7 and $58.9 \%$ in September and October, respectively), other green algae were detected during these months. Different species of the genus Chlorella such as C. kessleri (19.7 and 14.1\% in September and October, respectively) and C. minutissima (5.4 and 1.2\%, in September and October, respectively) were observed in the HRAP. Additionally, the lower temperatures and maximum monthly insulation in September and October mediated the dominance of cyanobacteria, which outcompeted the green algae. Hence, the genus Pseudanabaena represented 32.0 and $15.3 \%$ in September and October, respectively, the genus Aphanothece represented a relative abundance of $6.1 \%$ in September and the genus Leptolyngbya exhibited $10.5 \%$ of relative abundance in October. These results matched previous observations of photobioreactor systems dominated by a single algal species, including $C$. vulgaris, which population decreased when modifying the $\mathrm{C} / \mathrm{N}$ ratio [38] and the maximum photosynthetic radiation [37].

\subsection{Impact of the interaction algae-prokaryotes and the seasonal variation on the main biological communities found during operation}

The significant shifts in the prokaryotic diversity and community structure over time were likely due to the environmental seasonal variations, the algal population or a combination of both. To assess the influence of the seasonal variation on the algal and prokaryotic communities, an analysis of similarity ANOSIM was carried out and plotted throughout a non-metric dimensional scaling (NMDS) (Fig. 3). Moreover, the effect of each independent parameter was assessed throughout a canonical correspondence analysis (Table 5).

Based on the aforementioned results, the analysis of the effect of the algal population on the prokaryotic community structure was classified in dominated by "C. vulgaris" and "mixed community" (Fig. 3). The influence of the algal community structure on prokaryotic diversity was significant at $\mathrm{p}<0.05$. Multiple studies have reported the close interactions between algae and bacteria in photobioreactors

Table 4

Relative abundance of the algal community presented as relative abundance per sample (\%).

\begin{tabular}{|c|c|c|c|c|c|c|c|c|c|c|c|c|}
\hline Phylum & Family & Genus & Feb. & Mar. & Jul. & Aug. & Apr. & May & Jun. & Jan. & Sept. & Oct. \\
\hline \multirow{8}{*}{ Chlorophyta } & \multirow{8}{*}{ Trebouxiophyceae } & Chlorella vulgaris & 14.3 & $95.2^{*}$ & $100 * *$ & $100^{* *}$ & $100^{* *}$ & $100 * *$ & $100^{* *}$ & 12.0 & 36.7 & $58.9^{*}$ \\
\hline & & Chlorella kessleri & & & & & & & & & 19.7 & 14.1 \\
\hline & & Chlorella minutissima & & & & & & & & 2.1 & 5.4 & 1.2 \\
\hline & & Parachlorella kessleri & & & & & & & & 4.4 & & \\
\hline & & Tetradesmus obliquus & & & & & & & & 15.3 & & \\
\hline & & Scenedesmus pescensis & & 4.8 & & & & & & & & \\
\hline & & Desmodesmus opoliensis & 9.5 & & & & & & & & & \\
\hline & & Westsella $s p$ & $76.2^{*}$ & & & & & & & & & \\
\hline \multirow{5}{*}{ Cyanobacteria } & \multirow{5}{*}{ Cyanophiceae } & Cyanothece sp & & & & & & & & & & \\
\hline & & Leptolyngbya lagerheimiji & & & & & & & & $62.6^{*}$ & & 10.5 \\
\hline & & Pseudanabaena mucicola & & & & & & & & & 15.0 & \\
\hline & & Pseudanabaena $s p$ & & & & & & & & 3.5 & 17.0 & 15.3 \\
\hline & & Aphanothece saxicola & & & & & & & & & 6.1 & \\
\hline
\end{tabular}

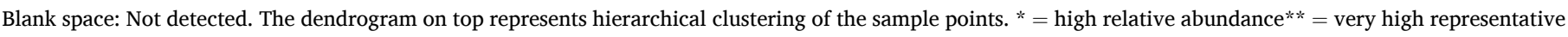
abundance. 


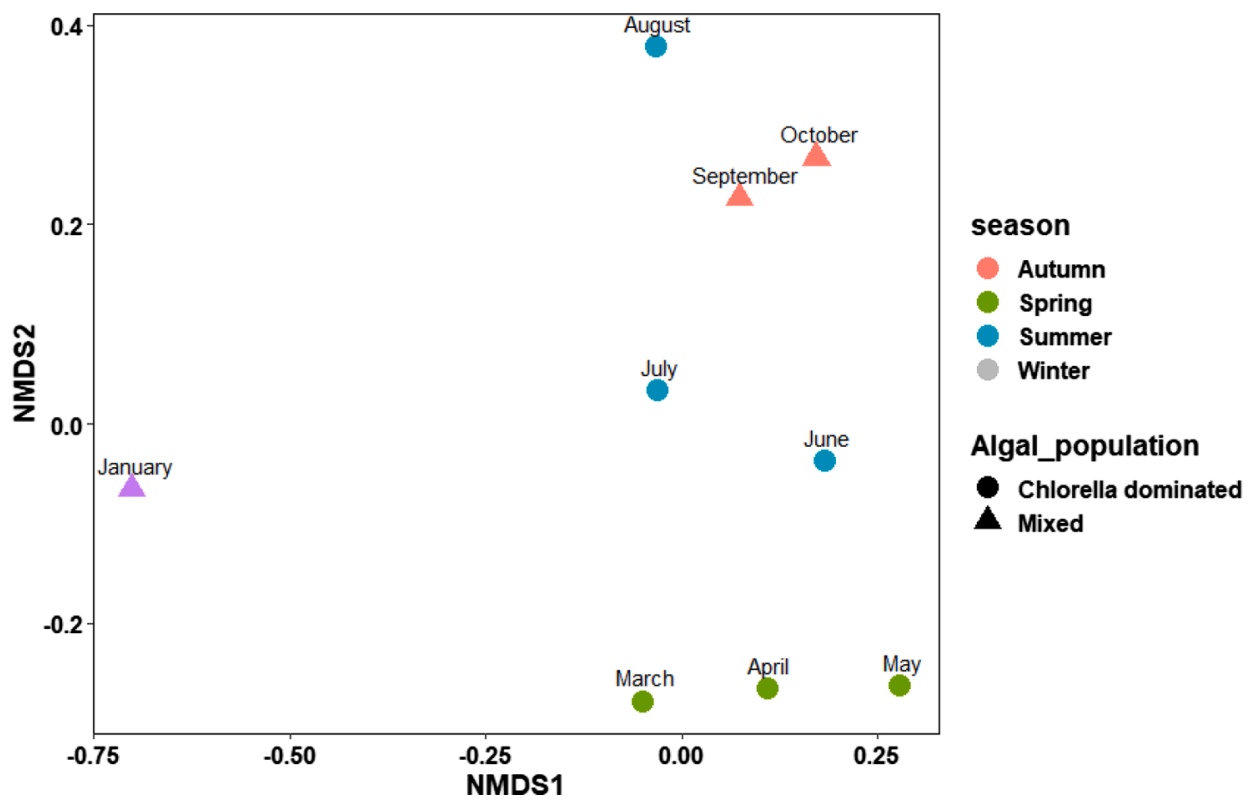

Fig. 3. Non-metric dimensional scaling (NMDS) of the prokaryotic abundance in relation to algal populations and seasonal variability. Stress $=0.21$.

Table 5

Influence of environmental and biological parameters on algal and bacterial populations. $*=$ statistically significant $\mathrm{p}<0.05 * *=$ statistically highly significant $\mathrm{p}<0.01$ based on canonical correspondence analysis.

\begin{tabular}{lll}
\hline Parameter & $\begin{array}{l}\text { p value influence algal } \\
\text { population }\end{array}$ & $\begin{array}{l}\text { p value influence } \\
\text { prokaryotic population }\end{array}$ \\
\hline Ambient temperature & $0.035^{*}$ & 0.260 \\
Temperature HRAP & $0.049^{*}$ & 0.221 \\
Maximum monthly & $0.006^{* *}$ & $0.044^{*}$ \\
$\quad$ insulation & & \\
pH & 0.146 & 0.755 \\
Dissolved oxygen & 0.216 & 0.114 \\
Inorganic carbon & 0.133 & 0.527 \\
$\mathrm{CO}_{2}$ gas phase & $0.017^{*}$ & 0.649 \\
$\mathrm{CH}_{4}$ gas phase & $0.001^{* *}$ & 0.538 \\
$\mathrm{O}_{2}$ gas phase & $0.046^{*}$ & 0.859 \\
$\mathrm{~N}_{2}$ gas phase & 0.346 & 0.129 \\
$\mathrm{~S}_{-} \mathrm{SO}_{4}^{2-}$ & 0.131 & 0.523 \\
$\mathrm{~N}^{*} \mathrm{NH}_{4}^{+}$ & $0.027^{*}$ & 0.059 \\
$\mathrm{~N}-\mathrm{NO}_{2}^{-}$ & 0.074 & 0.057 \\
$\mathrm{~N}^{-} \mathrm{NO}_{3}^{-}$ & $0.014^{* *}$ & $0.028^{*}$ \\
$\mathrm{P}^{*} \mathrm{PO}_{4}^{3-}$ & 0.268 & 0.084 \\
\hline
\end{tabular}

(commensalistic, mutualistic or antagonistic), which have demonstrated that the algal population and bacterial community depend on each other $[8,39]$. Additionally, seasonal environmental conditions exerted a significant effect on the algal and prokaryotic population with a $\mathrm{p}$ value $<$ 0.04 . Overall, the algal population was influenced by the majority of environmental parameters, while maximum monthly insulation was the main parameter affecting the prokaryotic population (Table 5; mmc: Fig. S17, S18).

The algal community structure was strongly influenced by the seasonal changes in the temperature and maximum monthly insulation along the year ( $p<0.035$ and $p<0.006$, respectively) (Table 5). The optimal temperatures for algal growth range from 28 to $35^{\circ} \mathrm{C}$, although this range is species specific [40]. C. vulgaris has a broad range of growth temperatures (from 10 to $37 \mathrm{C}$ ), although its growth is highly dependent on light intensity. Hence, it has been demonstrated that $C$. vulgaris growth is favored by high sun irradiance and photoperiods from 12 to $16 \mathrm{~h}$ (length of exposure to light) [21]. While other ubiquitous algal genera such as Desmodesmus have optimum growth rates under similar temperatures and solar irradiance ranges to $C$. vulgaris, the latter is a great competitor able to easily adapt to new conditions and displace other species $[41,42]$. However, winter and autumn conditions negatively affected $C$. vulgaris growth due to the lower maximum monthly insulation radiation and the colder temperatures prevailing in these periods. In this context, the cyanobacterial genera Pseudanabaena and Leptolyngbya can grow at lower light intensities, which allowed them to increase their concentration in autumn by $30 \%$. Indeed, cyanobacterial outbreaks have been observed in nature at the beginning of spring and autumn $[41,43]$.

The prokaryotic community was not correlated with temperature $(\mathrm{p}$ $<0.26$ ) (Table 5). However, the maximum monthly insulation significantly affected the community structure $(\mathrm{p}<0.044)$. This fact might be related to the presence of photosynthetic bacteria such as purple sulfur bacteria and green non sulfur bacteria. Previous works on the treatment of wastewater with an algae-bacterial consortium in photobioreactors suggested that the dominance of Chlorella was linked with the occurrence of the photosynthetic bacteria Rhodobacter and the dominance of cyanobacteria with the phylum Chloroflexi $[14,37]$. The same result was observed in this study, where cyanobacterial growth in September and October occurred concomitantly with the increase of the members of the genus Chloronema and Chloroploca, probably due to their capacity to outcompete other photosynthetic organisms at lower sun irradiances and photoperiods [44].

The $\mathrm{pH}$ of the HRAP cultivation broth affects many of the biochemical processes associated with algal growth and metabolism, including the bio-availability of $\mathrm{CO}_{2}$ for photosynthesis and the availability and uptake of nutrient ions [20]. In this research, the $\mathrm{pH}$ of the photobioreactor remained at $9.5 \pm 0.2$ during the entire operation as a result of the high buffer capacity of the cultivation broth. Thus, the slight $\mathrm{pH}$ seasonal variations did not have a statistically significant effect on the algal and prokaryotic community ( $\mathrm{p}<0.15$ and $\mathrm{p}<0.75$, respectively). The algal community was mainly composed of freshwater chlorophyte genera that can tolerate $\mathrm{pH}$ values up to $10.6-11$, such as Chlorella, Scenedesmus and Desmodesmus [11]. However, the impact of the other environmental conditions on the metabolism of microalgae resulted in C. vulgaris as the dominant species in the HRAP. Traditional alkaliphilic cyanobacteria such as Spirulina and Euhalothece were not present in the inoculum, however neutrophile cyanobacteria such as Pseudonabaena and Leptolyngbya increased and outcompeted the rest of algal species at $\mathrm{pH} 9$ when the temperature and maximum monthly insulation decreased. Interestingly, the majority of archaeal and 
bacterial genera identified did not belong to strict alkaliphilic groups and consisted of microorganisms able to grow in a wide spectrum of $\mathrm{pH}$. This fact could be correlated to the origin source, digestate from a wastewater plant working at $\mathrm{pH} 7$.

The concentrations of dissolved oxygen in the HRAP did not exert an effect on either the algal community $(\mathrm{p}<0.11)$ or on the prokaryotic community structure $(\mathrm{p}<0.22)$ (Table 5$)$. High oxygen concentrations in the culture broth $\left(>25 \mathrm{mgL}^{-1}\right)$ can have a negative influence on algal activity and cause shifts in the algal community structure. However, at the low-moderate concentrations of oxygen detected in this study, dissolved oxygen was not a detrimental factor for the algal community [20]. The majority of bacterial genera found during operation consisted of chemo-organoheterotrophs, fermenters and anoxygenic phototrophic bacteria. The first group consisted on facultative aerobic bacteria. Probably during the day hours, they fed from the oxygen produced by photosynthesis and at night they used nitrate as electron acceptor. Fermenters could have been aerobic or anaerobic, while in the case of the anoxygenic phototrophic bacteria, depending on the genus they can grow at high oxygen tensions. For example, some members of the genus Rhodobacter can carry out aerobic or photosynthetic metabolism in response to the oxygen tension and light [45].

Overall, a direct effect on the microbial community of the high $\mathrm{pH}$ and high nitrate concentrations, the dominant algal population (which produced oxygen), and the photoperiod was confirmed through this analysis. The bacterial community was dominated by photosynthetic bacteria, sulfur oxidizers, and aerobic and facultative aerobic chemoorganoheterotrophs, which are not characteristic of anaerobic digestion. Thus, the environmental parameters, algal population and the HRAP operational conditions promoted the enrichment and specialization of the bacterial groups obtained.

\subsection{Effect of the algal and prokaryotic community structure on HRAP performance}

To understand the effect on biogas upgrading and digestate treatment of the different organisms identified, a canonical correspondence analysis was conducted accompanied by a redundancy analysis (RDA) (Fig. S19; Table 5). As previously described, methane concentrations increased in the biogas during spring and summer, stabilizing at values of $95.2 \pm 0.7 \% \mathrm{CH}_{4}$, while $\mathrm{CO}_{2}$ was removed down to values of $1.4 \pm$ $0.1 \% \mathrm{CO}_{2}$ and $\mathrm{H}_{2} \mathrm{~S}$ was completely depleted. These values were achieved through the fixation of $\mathrm{CO}_{2}$ by the algal population and photosynthetic bacteria, oxygen consumption by the aerobic chemoorganoheterotrophs, and the oxidation of $\mathrm{H}_{2} \mathrm{~S}$ by the bacterial community. However, the canonical correspondence analysis showed that microalgae and cyanobacteria were the only microbial communities responsible for the seasonal variation of $\mathrm{CH}_{4}$ and $\mathrm{CO}_{2}$ concentrations (Table 5). The absence of correlation between the $\mathrm{CH}_{4}$ and $\mathrm{CO}_{2}$ concentration with the prokaryotic community structure was mainly due to the high $\mathrm{CO}_{2}$ removal rates supported by the algal population. The $\mathrm{CO}_{2}$ in the biomethane was always present at levels lower than $5 \%$, however, the high $\mathrm{pH}$ in the cultivation broth resulted in high bicarbonate ion concentrations. Members of the Chlorella genus are very versatile in tolerating a high range of $\mathrm{CO}_{2}$ concentrations, with a typical inhibitory threshold of above $40 \% \mathrm{CO}_{2}$. Additionally, the genome of Chlorella contains the enzyme carbonic anhydrase, which can increase bicarbonate assimilation and favor the dominance of this species [1]. Thus, the dominance of a resistant algal specie in the HRAP allowed the decrease of $\mathrm{CO}_{2}$ in the upgraded biogas. When Chlorella became the most dominant algal species in the HRAP, $\mathrm{CO}_{2}$ concentrations decreased from $4.5 \pm 0.6 \%$ down to average values of $1.4 \pm 0.1 \%$ (Table 2) in the upgraded biogas. Concomitantly, $\mathrm{CH}_{4}$ increased from values of $90.9 \pm$ $0.9 \%$ to values of $95.2 \pm 0.7 \% \mathrm{CH}_{4}$ (Table 2). Thus, the produced biomethane complied with $\mathrm{CH}_{4}$ and $\mathrm{CO}_{2}$ concentrations required to be used as a substitute for natural gas or auto gas [6].

$\mathrm{H}_{2} \mathrm{~S}$ was completely depleted during operation, while $\mathrm{SO}_{4}^{2-}$ concentrations increased in the cultivation broth mainly caused by sulfide bacterial aerobic oxidation $(\mathrm{p}<0.05)$. The dominance of sulfur oxidizers from the Chromatiaceae family became prevalent from April onwards concomitantly to an increase in sulfate detection (Fig. S19). Thus the bacterial population was essential to obtain upgraded biogas without $\mathrm{H}_{2} \mathrm{~S}$ traces. $\mathrm{N}_{2}$ and $\mathrm{O}_{2}$ concentrations in the biogas did not have a statistical effect on any of the target microbial populations (Table 5).

The algal community structure was not correlated to the concentration of nitrite $(\mathrm{p}<0.074)$, but it was influenced by the concentrations of nitrate and ammonium ( $\mathrm{p}<0.014$ and $\mathrm{p}<0.027$, respectively) (Table 5). While the genus Chlorella has a high tolerance to $\mathrm{NH}_{4}^{+}$, cyanobacteria experienced a significantly negative correlation with nitrate and ammonium concentrations [46]. Therefore, the enhanced growth of the cyanobacteria Pseudanabaena and Leptolyngbya in autumn could have been influenced by the reduction nitrate and ammonium concentration. A partial oxidation $\mathrm{N}-\mathrm{NH}_{4}^{+}$to nitrite could have been the source of nitrite. However, during the bacterial population analysis, we inferred -based on phylogeny- that next to anoxygenic photosynthesis, denitrification was- the second most common physiological process. During winter and spring periods members of the genera Acinetobacter, Comamonas and Caldilinea were the most representative nitrate reducers, while during summer and autumn, Aquibacter and the family Rhodanobacteraceae were dominant, accounting for 30 to $40 \%$ of the bacterial population. In this regard, $\mathrm{N}-\mathrm{NO}_{2}^{-}$and $\mathrm{N}-\mathrm{NO}_{3}^{-}$were produced by aerobic nitrifiers, and nitrite was probably accumulated as a result of $\mathrm{NO}_{3}^{-}$ reduction. Similar nitrite accumulation has been found in HRAP treating digestate $[4,47]$. In those studies, it was hypothesized that the dissolved oxygen concentrations in the HRAP and the moderate temperatures would inhibit full $\mathrm{NH}_{4}^{+}$nitrification, and a partial ammonium oxidation occurred. However, this research indicated that denitrification during the night may be the main physiologic process related with the transformation of nitrogen species in HRAP for biogas upgrading coupled with wastewater treatment. In this sense, the elimination of ammonium and nitrate was carried out by both bacteria and algae, which were able to reduce the concentrations of $\mathrm{NH}_{4}^{+}$and $\mathrm{N}^{-\mathrm{NO}_{3}^{-}}$by 88 and $78 \%$, respectively, in the treated wastewater. However, the increase of nitrite caused by biological denitrification increased the total nitrogen in the wastewater, making it unsuitable for discharge. Fortunately, the innovative photosynthetic biogas upgrading process coupled with wastewater treatment validated in this research was operated under a "zero effluent" strategy and therefore the quality of the treated water did not represent an operational issue.

The concentration of phosphate did not significantly affect the biological communities (Table 5). Phosphate concentrations were lower in the colder months, mainly due to phosphate precipitation at low temperatures. The concentration of phosphate increased from April onwards in the digestate and intra-cellularly. Some cyanobacteria and bacteria can accumulate phosphate as energy reservoir. In this study, phosphate accumulating genera such as the cyanobacterium Pseudanabaena sp. Acinetobacter, Rhodocyclus-like bacteria such as Thaurea, and other $\beta$-proteobacteria such as Comamonas were found [48].

\section{Conclusions}

The interactions between algae and prokaryotes and the influence of environmental parameters are key factors governing the performance of HRAPs devoted to biogas upgrading. The algal population was mainly responsible for $\mathrm{CH}_{4}$ and $\mathrm{CO}_{2}$ concentrations in the biomethane. The dominance of a versatile and resistant algae tolerant to high $\mathrm{NH}_{4}^{+}$and $\mathrm{CO}_{2}$ concentrations, such as $C$. vulgaris, concomitant to a specific prokaryotic population of sulfur bacteria, allowed for the obtention of biomethane with $95.2 \pm 0.7 \% \mathrm{CH}_{4}, 1.4 \pm 0.1 \% \mathrm{CO}_{2}$ and no $\mathrm{H}_{2} \mathrm{~S}$. Moreover, the dominant algal species impacted the structure of the bacterial community, which played a very important role on both biogas upgrading, through oxygen and $\mathrm{H}_{2} \mathrm{~S}$ elimination, and wastewater treatment. While the algal population was involved in the elimination of 
ammonium through assimilation, the bacterial population carried out the removal of organic carbon, phosphate, ammonium and nitrate from wastewater. However, the low oxygen concentrations of the HRAP at night supported anoxygenic photosynthesis and the accumulation of nitrite in the cultivation broth, which can be toxic at high concentrations, and diminishes the quality of treated wastewater. Thus, the use of an enriched bacterial inoculum composed of aerobic chemoorganoheterotrophs and aerobic nitrifiers, as well as sulfur bacteria and which lacks of nitrate reducers, together with a resistant dominant algae species, could be a promising platform to obtain high quality biomethane and treated wastewater in photobioreactors. This designed consortium can avoid the accumulation of nitrite in the cultivation broth, and reduce the content of oxygen in the produced biomethane In addition, the dominance of a versatile and resistant algae, such as C. vulgaris, concomitant to a specific prokaryotic population seems to enhance the resilience of process operation against fluctuations in environmental conditions.

\section{CRediT authorship contribution statement}

Sara Cantera: Conceptualization, Methodology, Validation, Formal Analysis, Investigation, Writing - original draft preparation, Visualization. Peter Q. Fischer: Methodology, Software, Validation, Data curation, Visualization. Irene Sanchez-Andrea: Supervision. David Marin: Resources. Diana Z. Sousa: Supervision, Writing - review \& editing. Raul Muñoz: Writing - review \& editing, Project administration, Funding acquisition.

\section{Declaration of Competing Interest}

The authors declare that they have no known competing financial interests or personal relationships that could have appeared to influence the work reported in this paper.

\section{Acknowledgements}

The Regional Government of Castilla y León and the EU-FEDER programme [grant numbers CLU 2017-09 and UIC 071] are gratefully acknowledged. The authors also thank Ramon Areces Foundation for the financial support of this work via sponsoring of Sara Cantera's Postdoctoral grant.

\section{Appendix A. Supplementary data}

Supplementary data to this article can be found online at https://doi. org/10.1016/j.fuel.2021.121148.

\section{References}

[1] Bose A, Lin R, Rajendran K, O'Shea R, Xia Ao, Murphy JD. How to optimise photosynthetic biogas upgrading: a perspective on system design and microalgae selection. Biotechnol Adv 2019;37(8):107444. https://doi.org/10.1016/j. biotechadv.2019.107444.

[2] Lian J, Wijffels RH, Smidt H, Sipkema D. The effect of the algal microbiome on industrial production of microalgae. Microb Biotechnol. 2018;11(5):806-18. https://doi.org/10.1111/mbt2.2018.11.issue-510.1111/1751-7915.13296.

[3] Ángeles R, Rodero R, Carvajal A, Muñoz R, Lebrero R. Potential of Microalgae for Wastewater Treatment and Its Valorization into Added Value Products. In: Gupta SK, Bux F, editors. Application of Microalgae in Wastewater Treatment: Volume 2: Biorefinery Approaches of Wastewater Treatment. Cham: Springer International Publishing; 2019. p. 281-315. https://doi.org/10.1007/978-3-03013909-4_13.

[4] Posadas E, Marín D, Blanco S, Lebrero R, Muñoz R. Simultaneous biogas upgrading and centrate treatment in an outdoors pilot scale high rate algal pond. Bioresour Technol 2017;232:133-41. https://doi.org/10.1016/j.biortech.2017.01.071.

[5] Toledo-Cervantes A, Madrid-Chirinos C, Cantera S, Lebrero R, Muñoz R. Influence of the gas-liquid flow configuration in the absorption column on photosynthetic biogas upgrading in algal-bacterial photobioreactors. Bioresour Technol 2017;225: 336-42. https://doi.org/10.1016/j.biortech.2016.11.087.
[6] Muñoz R, Meier L, Diaz I, Jeison D. A review on the state-of-the-art of physical/ chemical and biological technologies for biogas upgrading. Rev Environ Sci Bio/ Technol. 2015;14(4):727-59. https://doi.org/10.1007/s11157-015-9379-1.

[7] Marín D, Posadas E, Cano P, Pérez V, Blanco S, Lebrero R, et al. Seasonal variation of biogas upgrading coupled with digestate treatment in an outdoors pilot scale algal-bacterial photobioreactor. Bioresour Technol 2018;263:58-66. https://doi. org/10.1016/j.biortech.2018.04.117.

[8] Fuentes JL, Garbayo I, Cuaresma M, Montero Z, González-Del-Valle M, Vílchez C. Impact of Microalgae-Bacteria Interactions on the Production of Algal Biomass and Associated Compounds. Mar Drugs. 2016;14:100. https://doi.org/10.3390/ md14050100.

[9] Ramanan R, Kim B-H, Cho D-H, Oh H-M, Kim H-S. Algae-bacteria interactions: Evolution, ecology and emerging applications. Biotechnol Adv 2016;34(1):14-29. https://doi.org/10.1016/j.biotechadv.2015.12.003.

[10] Crits-Christoph A, Gelsinger DR, Ma B, Wierzchos J, Ravel J, Davila A, et al. Functional interactions of archaea, bacteria and viruses in a hypersaline endolithic community. Environ Microbiol 2016;18(6):2064-77. https://doi.org/10.1111/ 1462-2920.13259.

[11] Granada-Moreno CI, Aburto-Medina A, de los Cobos Vasconcelos D, GonzálezSánchez A. Microalgae community shifts during the biogas upgrading in an alkaline open photobioreactor. J Appl Microbiol 2017;123(4):903-15. https://doi. org/10.1111/jam.2017.123.issue-410.1111/jam.13552.

[12] Lopatkin AJ, Collins JJ. Predictive biology: modelling, understanding and harnessing microbial complexity. Nat Rev Microbiol 2020;18(9):507-20. https:// doi.org/10.1038/s41579-020-0372-5.

[13] Marín D, Posadas E, Cano P, Pérez V, Lebrero R, Muñoz R. Influence of the seasonal variation of environmental conditions on biogas upgrading in an outdoors pilot scale high rate algal pond. Bioresour Technol 2018;255:354-8. https://doi.org/ 10.1016/j.biortech.2018.01.136.

[14] Posadas E, Serejo ML, Blanco S, Pérez R, García-Encina PA, Muñoz R. Minimization of biomethane oxygen concentration during biogas upgrading in algal-bacterial photobioreactors. Algal Research. 2015;12:221-9. https://doi.org/10.1016/j. algal.2015.09.002.

[15] Kozich JJ, Westcott SL, Baxter NT, Highlander SK, Schloss PD. Development of a Dual-Index Sequencing Strategy and Curation Pipeline for Analyzing Amplicon Sequence Data on the MiSeq Illumina Sequencing Platform. Appl Environ Microbiol 2013;79(17):5112-20. https://doi.org/10.1128/AEM.01043-13.

[16] Phandanouvong-Lozano V, Sun W, Sanders JM, Hay AG. Biochar does not attenuate triclosan's impact on soil bacterial communities. Chemosphere 2018; 213:215-25. https://doi.org/10.1016/j.chemosphere.2018.08.132.

[17] Baselga A, Leprieur F, Spencer M. Comparing methods to separate components of beta diversity. Methods Ecol Evol 2015;6(9):1069-79. https://doi.org/10.1111/ mee3.2015.6.issue-910.1111/2041-210X.12388.

[18] R Core Team, R: A language and environment for statistical computing. R Foundation for Statistical Computing, Vienna, Austria., Vienna, Austria, 2019R Core Team, R: A language and environment for statistical computing. R Foundation for Statistical Computing, Vienna, Austria., Vienna, Austria; 2019.

[19] Oksanen J, Blanchet FG, Friendly M, Kindt R, Legendre P, McGlinn D, et al. Vegan: Community Ecology Package. R package version 2.5-6. HVegan: Community Ecology Package. R package version 2.5-6., Https://CRAN.R-Project.Org/ Package=vegan 13:34 2019;13:34

[20] Park JBK, Craggs RJ, Shilton AN. Wastewater treatment high rate algal ponds for biofuel production. Bioresour Technol 2011;102(1):35-42. https://doi.org/ 10.1016/j.biortech.2010.06.158.

[21] Metsoviti MN, Papapolymerou G, Karapanagiotidis IT, Katsoulas N. Effect of Light Intensity and Quality on Growth Rate and Composition of Chlorella vulgaris. Plants. 2020;9(1):31. https://doi.org/10.3390/plants9010031.

[22] Sander Rolf. Compilation of Henry's Law Constants for Inorganic and Organic Species of Potential Importance in Environmental Chemistry, 10 Copyright (c) 2010. ASME; 1999.

[23] Rodero R, Lebrero R, Serrano E, Lara E, Arbib Z, García-Encina PA, et al. Technology validation of photosynthetic biogas upgrading in a semi-industrial scale algal-bacterial photobioreactor. Bioresour Technol 2019;279:43-9. https:// doi.org/10.1016/j.biortech.2019.01.110.

[24] Sanz-Luque E, Chamizo-Ampudia A, Llamas A, Galvan A, Fernandez E. Understanding nitrate assimilation and its regulation in microalgae. Front Plant Sci 2015;6. https://doi.org/10.3389/fpls.2015.00899. 899-899.

[25] Gallert, C. Winter, J. Bacterial Metabolism in Wastewater Treatment Systems, in: Environmental Biotechnology, John Wiley \& Sons, Ltd; 2005: pp. 1-48. Doi: 10.1002/3527604286.ch1.

[26] Sun L, Toyonaga M, Ohashi A, Tourlousse DM, Matsuura N, Meng X-Y, et al. Lentimicrobium saccharophilum gen. nov., sp. nov., a strictly anaerobic bacterium representing a new family in the phylum Bacteroidetes, and proposal of Lentimicrobiaceae fam. nov. International J Systemat Evolut Microbiol 2016;66: 2635-42.

[27] Chen S, He S, Wu C, Du D. Characteristics of heterotrophic nitrification and aerobic denitrification bacterium Acinetobacter sp. T1 and its application for pig farm wastewater treatment. J Biosci Bioeng 2019;127(2):201-5. https://doi.org/ 10.1016/j.jbiosc. 2018.07.025.

[28] Hiraishi A, Muramatsu K, Urata K. Characterization of new denitrifying Rhodobacter strains isolated from photosynthetic sludge for wastewater treatment. J Ferment Bioeng 1995;79(1):39-44. https://doi.org/10.1016/0922-338X(95) 92741-T.

[29] Pohlner M, Dlugosch L, Wemheuer B, Mills H, Engelen B, Reese BK. The Majority of Active Rhodobacteraceae in Marine Sediments Belong to Uncultured Genera: A 
Molecular Approach to Link Their Distribution to Environmental Conditions. Front Microbiol 2019;10:659. https://doi.org/10.3389/fmicb.2019.00659.

[30] Nag Dasgupta, C. Singh, V.K. Nayaka, S. Kishore, S. Lavania, S. Molecular phylogeny of a commercially important thermophilic microalga Chlorella sorokiniana LWG002615 and associated bacterium Aquimonas sp. NBRI01 isolated from Jeori thermal spring, Shimla, India, The Nucleus; 2019. https://doi.org/ 10.1007/s13237-019-00286-z.

[31] Kragelund C, Thomsen TR, Mielczarek AT, Nielsen PH. Eikelboom's morphotype 0803 in activated sludge belongs to the genus Caldilinea in the phylum Chloroflexi. FEMS Microbiol Ecol 2011;76:451-62. https://doi.org/10.1111/j.15746941.2011.01065.x.

[32] Imhoff Johannes F. In: The Prokaryotes. Berlin, Heidelberg: Springer Berlin Heidelberg; 2014. p. 151-78. https://doi.org/10.1007/978-3-642-38922-1_295.

[33] Liu J-R, Tanner RS, Schumann P, Weiss N, McKenzie CA, Janssen PH, et al Emended description of the genus Trichococcus, description of Trichococcus collinsii sp. nov., and reclassification of Lactosphaera pasteurii as Trichococcus pasteurii comb. nov. and of Ruminococcus palustris as Trichococcus palustris comb. nov. in the low-G $+\mathrm{C}$ gram-positive bacteria. Int J Syst Evol Microbiol 2002 52:1113-26.

[34] Castignetti D, Hollocher TC. Heterotrophic nitrification among denitrifiers. Appl. Environ. Microbiol. 1984;47:620-3.

[35] Naushad S, Adeolu M, Wong S, Sohail M, Schellhorn HE, Gupta RS. A phylogenomic and molecular marker based taxonomic framework for the order Xanthomonadales: proposal to transfer the families Algiphilaceae and Solimonadaceae to the order Nevskiales ord. nov. and to create a new family within the order Xanthomonadales, the family Rhodanobacteraceae fam. nov. containing the genus Rhodanobacter and its closest relatives. Antonie Van Leeuwenhoek 2015;107(2):467-85. https://doi.org/10.1007/s10482-014-0344-8.

[36] Hanson RS, Hanson TE. Methanotrophic bacteria. Microbiol Rev 1996;60:439.

[37] García D, de Godos I, Domínguez C, Turiel S, Bolado S, Muñoz R. A systematic comparison of the potential of microalgae-bacteria and purple phototrophic bacteria consortia for the treatment of piggery wastewater. Bioresour Technol 2019;276:18-27. https://doi.org/10.1016/j.biortech.2018.12.095.

[38] Toledo-Cervantes Alma, Posadas Esther, Bertol Isabel, Turiel Sara, Alcoceba Ana, Muñoz Raúl. Assessing the influence of the hydraulic retention time and carbon/ nitrogen ratio on urban wastewater treatment in a new anoxic-aerobic algal- bacterial photobioreactor configuration. Algal Research. 2019;44:101672. https:// doi.org/10.1016/j.algal.2019.101672.

[39] Ramanan R, Kim B, Cho D, Oh H, Kim H. Algae-bacteria interactions: Evolution, ecology and emerging applications. Biotechnol Adv 2016;34(1):14-29. https://doi. org/10.1016/j.biotechadv.2015.12.003.

[40] Pawlita-Posmyk M, Wzorek M, Płaczek M, Gradziel S, Łopata S, Sobota T, et al. The influence of temperature on algal biomass growth for biogas production. MATEC Web Conf. 2018;240:04008. https://doi.org/10.1051/matecconf/201824004008.

[41] Ji X, Verspagen JMH, Stomp M, Huisman J. Competition between cyanobacteria and green algae at low versus elevated CO2: who will win, and why? J Exp Bot. 2017;68:3815-28. https://doi.org/10.1093/jxb/erx027.

[42] Nzayisenga JC, Farge X, Groll SL, Sellstedt A. Effects of light intensity on growth and lipid production in microalgae grown in wastewater. Biotechnol Biofuels 2020; 13:4. https://doi.org/10.1186/s13068-019-1646-x.

[43] Van der Grinten E, Janssen APHM, de Mutsert K, Barranguet C, Admiraal W. Temperature- and Light-Dependent Performance of the Cyanobacterium Leptolyngbya Foveolarum and the Diatom Nitzschia Perminuta in Mixed Biofilms. Hydrobiologia 2005;548(1):267-78. https://doi.org/10.1007/s10750-005-5324-6.

[44] Hanada S. The Phylum Chloroflexi, the Family Chloroflexaceae, and the Related Phototrophic Families Oscillochloridaceae and Roseiflexaceae. In: Rosenberg E, DeLong EF, Lory S, Stackebrandt E, Thompson F, editors. The Prokaryotes: Other Major Lineages of Bacteria and The Archaea. Berlin Heidelberg, Berlin, Heidelberg: Springer; 2014. p. 515-32. https://doi.org/10.1007/978-3-642-38954-2 165.

[45] Hamilton TL. The trouble with oxygen: The ecophysiology of extant phototrophs and implications for the evolution of oxygenic photosynthesis. Free Radical Biol Med 2019;140:233-49. https://doi.org/10.1016/j.freeradbiomed.2019.05.003.

[46] Gao J, Zhu J, Wang M, Dong W. Dominance and Growth Factors of Pseudanabaena sp. in Drinking Water Source Reservoirs. Southern China, Sustainability. 2018;10 (11):3936. https://doi.org/10.3390/su10113936.

[47] Norvill ZN, Toledo-Cervantes A, Blanco S, Shilton A, Guieysse B, Muñoz R Photodegradation and sorption govern tetracycline removal during wastewate treatment in algal ponds. Bioresour Technol 2017;232:35-43. https://doi.org/ 10.1016/j.biortech.2017.02.011.

[48] Tarayre C, Nguyen H, Brognaux A, Delepierre A, De Clercq L, Charlier R, et al. Characterisation of Phosphate Accumulating Organisms and Techniques for Polyphosphate Detection: A Review. Sensors (Basel). 2016;16(6):797. https://doi. org/10.3390/s16060797. 